\title{
The Rainbow Site, An Unusual Syrup Mill in Gregg County, Texas
}

\section{S. Alan Skinner Unknown}

Follow this and additional works at: https://scholarworks.sfasu.edu/ita

Part of the American Material Culture Commons, Archaeological Anthropology Commons, Environmental Studies Commons, Other American Studies Commons, Other Arts and Humanities Commons, Other History of Art, Architecture, and Archaeology Commons, and the United States History Commons

Tell us how this article helped you.

This Article is brought to you for free and open access by the Center for Regional Heritage Research at SFA ScholarWorks. It has been accepted for inclusion in Index of Texas Archaeology: Open Access Gray Literature from the Lone Star State by an authorized editor of SFA ScholarWorks. For more information, please contact cdsscholarworks@sfasu.edu. 


\section{The Rainbow Site, An Unusual Syrup Mill in Gregg County, Texas \\ Creative Commons License \\ (c) $($ ) $(9)$}

This work is licensed under a Creative Commons Attribution-NonCommercial 4.0 International License 


\title{
THE RAINBOW SITE, AN UNUSUAL SYRUP MILL IN GREGG COUNTY, TEXAS
}

\author{
S. Alan Skinner (AR CONSULTANTS, INC., DALLAS)
}

\begin{abstract}
The Rainbow site is a historic archaeological site that was recorded during a cultural resources survey of a proposed Wal-Mart SuperCenter site in Longview, Texas. It was first interpreted as the location of an illegal whiskey still, but testing revealed that the furnace had been part of a sugar cane syrup mill. The early 1900 s furnace is unusual when compared to other reported furnaces in that the firebox had been constructed below the original ground level and the flue/pan area had walls that were barely 1.5 ft. above the surrounding ground, whereas most furnaces were constructed on level ground and had waist-high walls where workers could stand upright when processing syrup. In addition, a brick vault had been constructed over the north end of the firebox and no other examples of such a feature have been reported from syrup mill furnaces.
\end{abstract}

The farm complex included the house, the barns, and all the outbuildings necessary for a family to maintain its self sufficiency... As the farmer prospered he built water tanks and milk houses and stock troughs. He fashioned a long furnace with a chimney to hold the long pan for making syrup...The placing of buildings was for the greatest efficiency, with the milk house and smoke house near enough for the wife to use easily, and the outhouse and hog pens and chicken house far enough away to dilute their characteristic aromas... All of it made one architectural whole, a working unit that served its maker with its greatest efficiency. (Abernethy 1979:147)

The Rainbow site was first encountered during an archaeological survey of a proposed Wal-Mart SuperCenter in northwest Longview, Texas. The site appeared as a 4 $\mathrm{m}$ long pile of sandstone blocks associated with a cone-shaped depression situated at the south end of the rock pile. Rocks and broken commercial bricks were scattered on the ground surface and were exposed in the depression walls. The depression was slightly more than $1 \mathrm{~m}$ deep and was slightly less than $2 \mathrm{~m}$ wide at ground level. Leaves and ground cover were cleared from the surface of the site and a dark brown stain was observed adjacent to the south side of the depression. The initial site evaluation concluded that this early 1900 s historic feature might have been an illegal whiskey still even though its configuration more resembled a sugar cane syrup mill furnace. The site was then tested to determine its function and to better define its period of construction and use in order to make an evaluation of its significance and whether it may be eligible for consideration in the National Register of Historic Places. 
The site is located in the forested region of East Texas. The topography of the surrounding area is the dissected rolling upland near the upper end of the watershed on the west side of Grace Creek.

A 1939 aerial photograph of the site area shows an unfarmed rectangular field to the south of the site. Farmed fields are shown to the west and south. The site area is treecovered and subsequent photographs in 1963, 1970, and 1979 show the field gradually being invaded by brush and trees. A dense tree cover is apparent on a 1990 aerial photograph. The only major clearing is south of the site area and had been completely cleared of trees to allow for energy exploration/storage. No evidence of historic residences in the site area was found on any of these historic pictures.

The history of the Longview area in Gregg County presents an interesting patchwork of developments related to how the early settlers recognized and then utilized the natural resources of the region. The following discussion was prepared primarily using Traditions of the Land, The History of Gregg County, Texas and Longview, Texas Centennial, the long view of a hundred years, 1870-1970(Longview Centennial Book Committee 1970; McWhorter 1989)

The Gregg County area was first settled before the Texas Revolution. Longview was established in 1870 as the town grew up around the Southern Pacific Railroad depot as the railroad line expanded west from Marshall. The Southern Pacific plans for the line west were terminated when the federally-mandated one year old Texas and Pacific Railroad Company (T\&P) took charge of building the railroad to the west. Gregg County was proposed in 1872 and included parts of Rusk and Harrison counties along with a small part from Upshur County. By the turn of the $20^{\text {th }}$ century, lumbering and cotton farming were big business. Longview was regarded as a sawmill community in the early $1900 \mathrm{~s}$. Cotton was an important agricultural product beginning in the $1850 \mathrm{~s}$, but over time the soil became depleted and less and less cotton was being produced by the $1920 \mathrm{~s}$.

The site was first recognized on the basis of what appeared to be a linear pile or mound of sandstone blocks located on the eastern edge of a dry drainage. The linear rock pile was oriented roughly north-south and appeared to be at least $0.5 \mathrm{~m}$ higher than the surrounding landform. Sandstone rocks were scattered on the surface of the mound and covered an area slightly more than $4 \mathrm{~m}$ long and approximately $2 \mathrm{~m}$ wide. It appeared that the rocks had been stacked to form the walls of a roughly U-shaped feature possibly with a chimney at the north end. An oak tree had grown through a barrel hoop (see HI on Figure 1) that is just north of the mound and two additional barrel hoops were nearby on the surface. Pieces of commercially-made pressed bricks were found on the surface throughout the site area and a hand-made chimney top of sheet metal was on the slope near the southwest corner of the mound. The chimney top is made of sheet metal that is 1/16-inch thick and from a roughly cut sheet that ranged from $61 / 2-63 / 4$ inches wide and 16 inches long. It had been formed into a roughly square cylinder cut on three corners to create a perpendicular flange that ranged from $7 / 8$-inch to $11 / 6$-inch wide. The flange ends had been riveted together and the nail holes through the flange indicate that it was anchored to a wooden structure. 
A second feature was also included as part of this historic site. The feature was an inverted cone-shaped depression that was located adjacent to the southern end of the rock mound (see Figure 1). The depression was more than $1 \mathrm{~m}$ deep and about $2 \mathrm{~m}$ wide and had been excavated into the native upland soil. Bedrock was not apparent in the walls of the hole and no artifacts were found inside the hole. Several pieces of sandstone and commercial bricks were encountered on the adjacent surface to the southeast and south of the hole. These bricks included four different colors, but the only identifiable bricks had the name "COLEMAN" impressed into one face. A single hand-made brick was also noted on the surface. An accumulation of ash was found on the surface south of the hole. The accumulation contained several small pieces of burned sandstone and brick fragments, but no metal, glass, or ceramic artifacts were noted in this apparently thin layer of material that may have been scraped from a fire. No other historic artifacts were found on the surface.

In order to investigate the site, it was important to further clear the ground surface and map the location and types of rocks, bricks, and other artifacts present and then to explore the buried deposits to determine the construction and function of the features present (Figure 1). Based on the diameter of trees in the immediate vicinity, it appeared that the area had been timbered 50-70 years ago, and may have been kept relatively clear of brush until the past 20 years. Thus, an area extending outside the rock and brick scatter was cleared of leaves, brush, and groundcover and then a $1 \mathrm{~m}$ grid was imposed over the surface of the entire cleared area. A detailed contour map was prepared that showed the location of surface artifacts, including rocks and bricks.

The subsurface exploration began by the excavation of a $1 \times 1 \mathrm{~m}$ unit that was placed in the dark brown/black stained area adjacent to the depression that had been noted during initial leaf/brush clearing. Fill was removed in $10 \mathrm{~cm}$ levels and was screened through 1/4-inch hardware cloth screens. Excavation then proceeded to two $1 \mathrm{x}$ $1 \mathrm{~m}$ units located inside the apparent furnace walls, one near the southern end of the furnace and the other at the northern end. Subsequently, units were placed outside the walls adjacent to the southern unit in the furnace.

Test Unit 1 was excavated in the ash-stained area (see Figure 1) and revealed that the matrix was wood charcoal and ash mixed with an unconsolidated sandy loam that was penetrated by a dense layer of small roots that formed a thick mat just below the surface. Two rusted wire nails ( $12 \mathrm{~d}$ and $30 \mathrm{~d}$ ), portions of five unfaced bricks, and a burned piece of sandstone were found in the first level along with small pieces of rusted metal, flakes of wood charcoal, and the worn-down tooth from an insert tooth saw blade (Figure 2a). This tooth could be from a 40 inch diameter blade (Winstead, 2001 personal communication). The charcoal-stained matrix continued in levels 2 and 3 , but decreased in area with depth in the southeastern corner of the unit. No black matrix was encountered in level 4 and undisturbed ground surface was reached by $50 \mathrm{~cm}$. Two additional saw teeth were found in level 2 along with two wire nails ( $30 \mathrm{~d}$ and 50d) and three brick fragments. One of the bricks was handmade, one was an unfaced commercial brick, and the other had the impression "COLE.." and is probably from the Coleman 


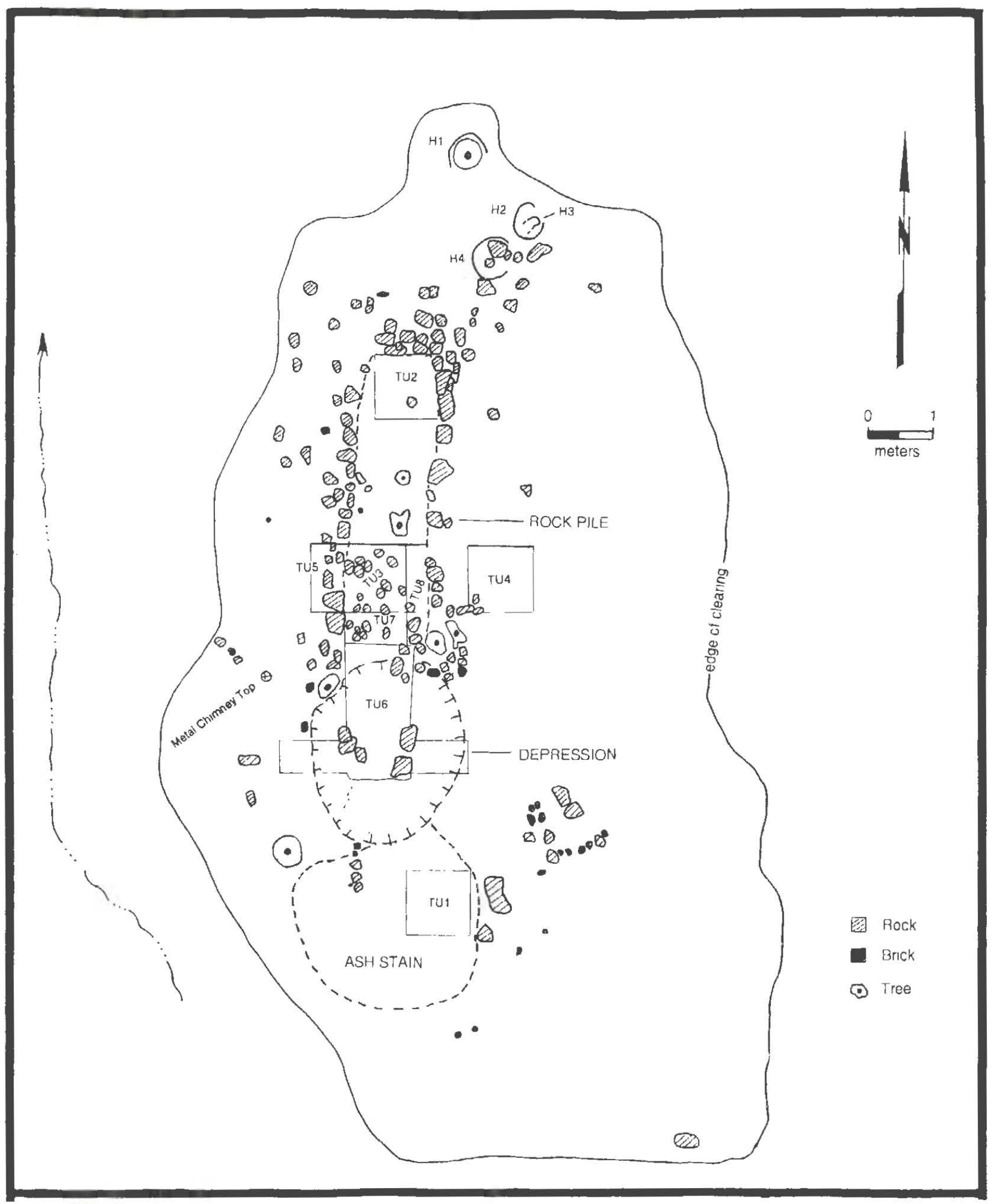

Figure 1. Base map of the Rainbow site showing the extent of clearing, rock fall, surface scatter, and the location of numbered excavation units. 


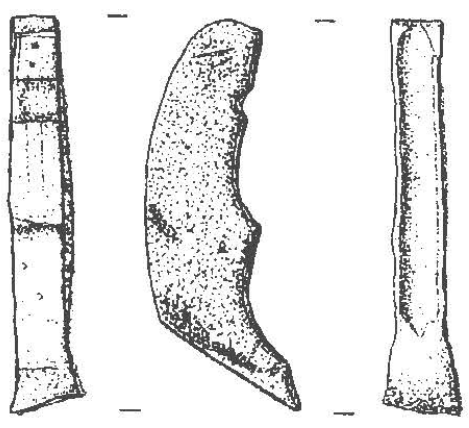

a

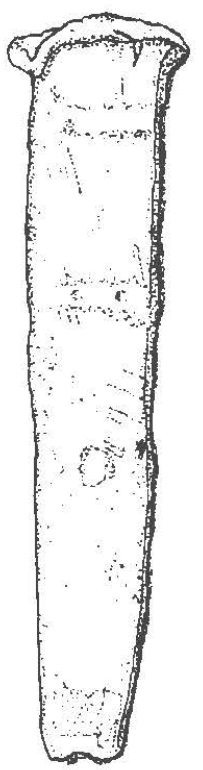

b

Figure 2. Metal artifacts. a, insert saw tooth; b, cut spike. Illustrated full-size by Lance K. Trask.

Brick Company. No artifacts were encountered in levels 3 or 4 . Excavation was discontinued at the base of level 5 after the undisturbed original ground surface was encountered.

Test Unit 2 was placed inside the north end of the rock outline (see Figure 1) in anticipation of encountering stone-lined walls and a floor. Excavation uncovered rocks and commercial bricks in the dark yellowish-brown (10YR7/6) sandy loam fill. A welldefined floor was not encountered, but a thin $(10-15 \mathrm{~cm})$ layer of apparently burned yellowish-red (5YR5/8) sandy clay was encountered about $35 \mathrm{~cm}$ below the present ground surface. This was not a continuous layer throughout the unit, and under it was a grayish-brown (10YR5/2) moist sand which appeared to be the natural ground surface. Excavation was continued to below $60 \mathrm{~cm}$, but no cultural material or wall foundation was encountered below the yellowish-red sandy clay surface. Two crude courses of sandstone rock were exposed in the north and east walls. The rocks were largely unshaped and were not joined with a recognized mortar, thus the walls appeared to have been built up only slightly on the ground surface and certainly did not present a prepared masonry wall façade. In addition to several commercial bricks, other artifacts in the fill 
included four $10 \mathrm{~d}$ wire nails and a heavily rusted belt or harness buckle. The buckle measures 2 inches in length and 1.5 inches wide.

Test Unit 3 was placed inside the rock outline (see Figure 1) and situated between trees that had grown inside the rock outline just to the north and the south. A large number of sandstone rocks and several bricks were found in the upper $20 \mathrm{~cm}$ of fill in Unit 3. As with Unit 2, a clear floor surface was not encountered but a burned surface was found and is shown in the furnace profile. Five wire nails ( $10 \mathrm{~d}, \mathrm{n}=1,16 \mathrm{~d}, \mathrm{n}=3$, and $20 \mathrm{~d}, \mathrm{n}=1$ ), a rusted threaded metal plug with a $7 / 8$-inch square head, and the base to a 5 inch mill file were found in the fill. Excavation continued to $50 \mathrm{~cm}$, but no artifacts were encountered below $20 \mathrm{~cm}$.

This unit was expanded by the excavation of Units 4 and 5 to the east and west, respectively, in order to better define the rock walls. No identifiable artifacts, other than brick fragments, were recovered from either unit, and no evidence of a work surface was encountered. Although rocks were present in the fill, no wall collapse was apparent, thus confirming that the rock walls had not been significantly higher.

Excavation began in the depression with the excavation of a $2 \times 0.5 \mathrm{~m}$ trench (Test Unit 6) that ultimately was expanded to the north and south in order to define the walls of the buried feature that was encountered. Units 7 and 8 were also excavated to verify the wall extent and the feature's floor. Several large blocky pieces of sandstone appeared to define the southern edges of the firebox that extended to the northern edge of Test Unit 6. No evidence was found that these rocks represented a masonry wall and it appeared that fill from the depression had been deposited on the adjacent slope to the west. This created a ramp or bench that extended more than $1 \mathrm{~m}$ beyond the edge of the depression and may represent post-abandonment exploration of the depression. In addition, several large pieces of cast iron were found in the upper fill of the depression and even extending south of the hole. These pieces may have been associated with the furnace, but they are dissimilar to any artifacts seen in other sites in the area.

A color change that was tentatively identified as the feature floor was encountered at the inside of the roughly defined rock wall and was followed to the edges of the unit to the north, east, and west. The sandy loam fill in this area contained numerous pieces of broken commercial bricks and several hand-made bricks as well as pieces of sandstone. The fill was not ash-stained like the deposit just to the south of the depression and no obvious vertical stratigraphy was apparent in the fill. Five wire nails ( $10 d, n=212 d, n=1$, $16 \mathrm{~d}, \mathrm{n}=1$ and $20 \mathrm{~d}, \mathrm{n}=1$ ] and two cut metal spikes (see Figure $2 \mathrm{~b}$ ) were recovered from the floor fill. The spikes were 3 inches and $35 / 8$ inches long. The floor was a mottled sandy loam matrix that was distinct but not compact until near the north end of the floor. In contrast, the natural clay walls were baked red (2.5YR4/6) to dark red (2.5YR4/8) in color. The burned wall extended to a height of $43 \mathrm{~cm}$ on the west side and $41 \mathrm{~cm}$ on the east side. The heated clay had a thickness of $7 \mathrm{~cm}$ in the west wall and gradually changed to a yellowish-red $(5 Y \mathrm{R} 4 / 6)$ color with a similar change at $6 \mathrm{~cm}$ in the east wall. All three walls were vertical and the floor to wall junction was smooth and not abrupt. 
Four courses of bricks were found first above the burned clay in the wall on the east side of the feature. The inner surface of some of the bricks had been glazed due to intense heat and the bricks had been laid so as to have been the base to a vaulted roof over the feature. Other bricks with glazed surfaces were found in the fill and on the surface of the site. Three courses of brick were found in a similar position above the west wall, which had been more heavily disturbed by root displacement. These bricks also had glazed surfaces and were placed in such a way as to have been the other end of the brick vault. Based on brick placement, it appeared that the vault was only three or four bricks wide with one brick anchored north in the southwest corner of Test Unit 7. The first course of bricks on the west side was positioned perpendicular to the wall and the second course was oriented parallel to the wall. The third course was arranged like the first course. A similar pattern was recorded in the four courses of the eastern brick vault. The bricks had been mortared in place, but no evidence was found that the inner face of the bricks had been covered with mortar, and the presence of glazed surfaces on some of the bricks indicated that the sand in the clay bricks had melted due to the intense heating that occurred in the feature.

At the conclusion of testing, it was apparent that a furnace had been uncovered, and that the function of the furnace was as a sugar cane syrup mill and most certainly not a whiskey still. The furnace consists of two primary parts: the firebox and the flue or pan area (Figure 3). The firebox is located at the south end of the furnace and below the level of the flue floor. The firebox area had initially been described as a depression, but excavation revealed that it is roughly rectangular in plan shape and adjoins the flue. The south end of the firebox had no obvious walls but large sandstone rocks defined the limits of the firebox. These rocks and other rocks throughout the site had been imported to the site area, as rocks of this type are not available on the surface in the surrounding area. A significant hole had been dug in order to build the firebox below the level of the natural ground surface. The east and west walls of the firebox are fire-hardened native clays that had been smoothed but showed no mortar over the rocks or the bricks. The firebox floor was not heavily burned nor did it contain a distinct ash layer. It must have been cleared regularly. The brick vault that had been constructed over the end of the firebox is a most unusual feature. The vault spanned a distance of $1 \mathrm{~m}$ and was only four bricks wide.

The nails and spikes found in the floor fill are attributed to the burning of wood which coincidentally contained them. The large cast iron pieces found in the fill of the depression, and in the case of the largest pieces, extended south from above the rocks that defined the south wall of the firebox. They are not part of the firebox and appear to be trash discarded into the pit some time after the firebox had been abandoned.

The flue extended north from the firebox (see Figure 3) for a distance of $4.5 \mathrm{~m}$ and averaged $1.15 \mathrm{~m}$ wide. Two courses of sandstone blocks created the walls of the flue and had been placed on the original ground surface at the south end, creating a wall that was about $46 \mathrm{~cm}$ tall. The floor of the flue had been built up to the north in order to insure a generally level top for the walls of the flue on which to place the evaporative pan. It is possible that an additional course of sandstone had been on top of the rocks 

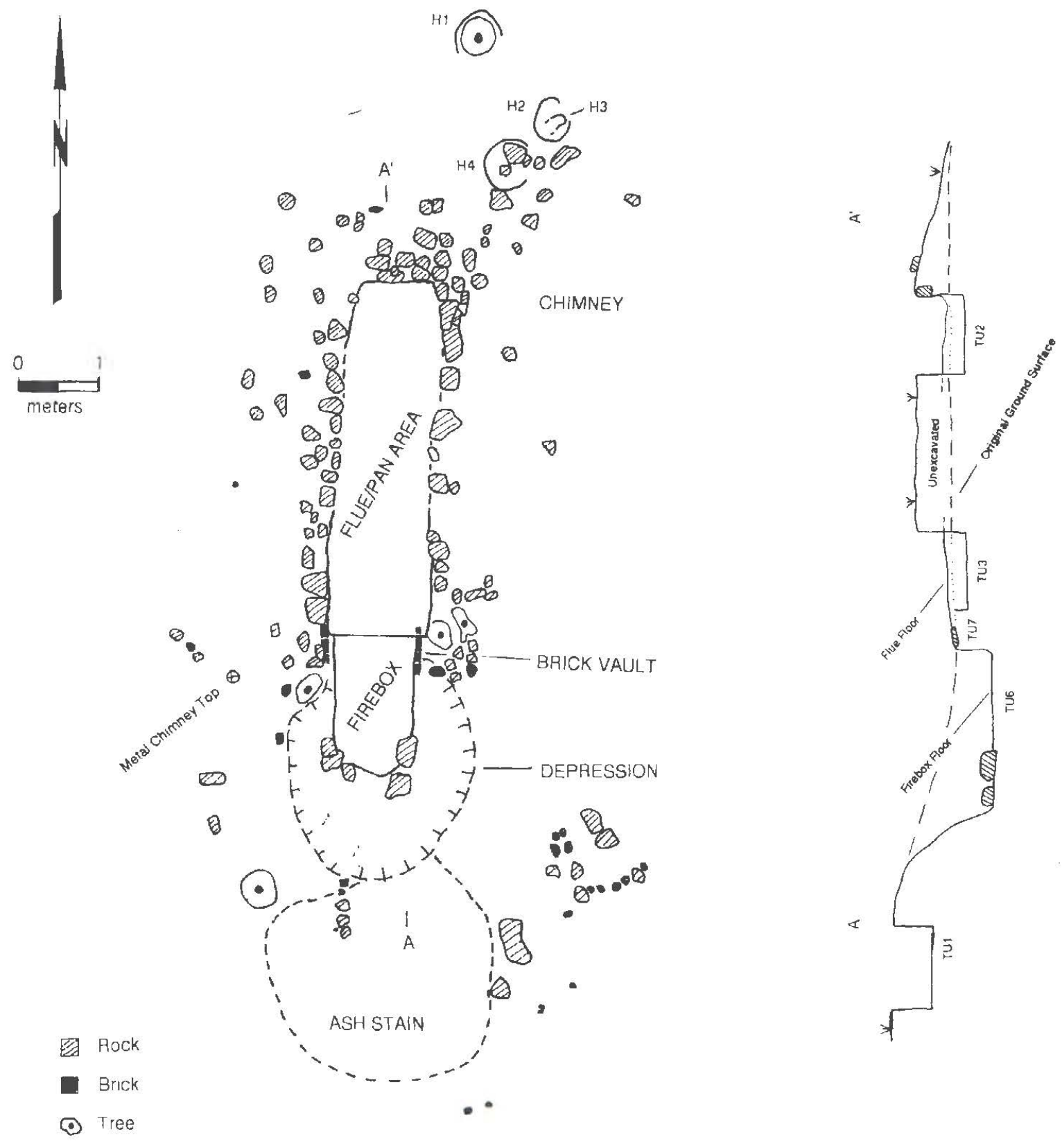

Figure 3. Plan map of the Rainbow site showing the funclions of the features uncovered during excavation and a profile showing the floors and original ground surface. 
exposed on the surface, but certainly not more than one more course based on the rocks present.

The sandstone blocks may have been plastered with clay or poor quality mortar, but the walls of the flue had not been fired as had the firebox walls. The floor of the flue had a distinct color, but was not a prepared surface. The space between the base of the pan and the floor was apparently sufficient to allow for good draw of the hot air needed for evaporation. No clear evidence of a rock chimney was found at the north end of the flue, and the metal chimney top, if that is what it is, was not found near the presumed chimney location. Almost no complete bricks were recovered from the site and the only confirmed evidence of brick use was in the vault over the firebox. Based on the abundance of brick fragments found and the variety of brick types present, it is likely that a row of bricks was placed on top of the stone walls to provide a smooth surface and a good seal for an evaporative pan. However, the variety of bricks indicates that their selection was the result of what was available and not a planned action.

Ash and charcoal were apparently removed from the firebox and dumped on the adjacent ground to the south. The accumulation covered an area roughly $2.4 \mathrm{~m}$ in diameter and the build up probably represents the residue from several seasons of use.

Dating construction and site use is tentative based on the artifacts. The presence of wire nails indicates that the furnace was built in the 20th century (Fontana 1965). The nails may have been used in the construction of some part of the furnace or a superstructure that provided shade or storage. They may also have been included in wood burned in the firebox. The metal spikes provide no clue to age and the saw teeth recovered from the ash stain have been used throughout the 20 th century and were also used in the late $1800 \mathrm{~s}$.

Bricks at the site included pieces of several hand-made bricks that were probably manufactured before 1900 . The remaining bricks were commercially manufactured in the 20 th century. A variety of manufacturers were represented by bricks with the names Atlas, Butler, Coleman, Palmer, and Texas. Coleman bricks were the most common type and may have been made by the Athens Brick \& Tile Company, the Harbison-Walker Refractories Company, or the Coleman Brick \& Tile Company. According to Gurcke (1987:218-219), Athens was making Coleman bricks from 1927-1935 and HarbisonWalker was advertising them in 1942. Atlas bricks are reported from several Texas cities (Graves 1996:392, 394-396), although Gurcke(1987:204-205) lists Atlas only from California, Ohio, and Pennsylvania. Palmer bricks were manufactured in Palmer and Palestine (Graves 1996:200, 2001), but manufacturing dates are not available. Texas bricks were advertised by Acme Brick Company from 1921-1925 and by General Refractories Company in 1942. Graves (1996) lists brick companies with the name "TEXAS" in at least nine cities within the state.

Based on the bricks and nails, we are confident that the Rainbow site was constructed in the early part of the 20th century. The arrangement of firebox and flue are evidence that the furnace probably was used for the evaporative conversion of sugar cane 
juice into cane syrup. It is interesting to note that the firebox was placed below the natural ground surface and that the flue walls were less than $0.6 \mathrm{~m}$ above the ground. In general, sugar cane furnaces are constructed on level ground and with walls that stand waist high to make moving the sugary liquid through the evaporation pan easy. Furthermore, the presence of the brick vault over part of the firebox is unusual. While the furnace does not appear to have been an integral part of an existing farm complex, one must have been in the vicinity. Certainly this upland location is not a place where sugar cane would have been grown and there must have been a farm probably to the south outside the survey area.

Although we had anticipated that the Rainbow site was an illegal whiskey still, the structure itself is decidedly longer than whiskey stills found in nearby Wood County and elsewhere in the eastern United States (Skinner and Kent 2000:28-30). However, the still at the Payton Pullen site in Wood County is a small version of the Rainbow site furnace with the added presence of a standing chimney at the end of the very low masonry furnace. A flowing spring is immediately adjacent to the still and the site is also located in at the edge of the Big Sandy Creek floodplain in what would be described as a secluded location, and thus water would have been readily available.

Sugar cane harvesting and processing has been an important part of the local economy in East Texas and Coastal Texas for more than 150 years. One needs only to look at the cover of the recent book titled The Slave Narratives of Texas by Ron Tyler and Lawrence R. Murphy (1997) to see part of a painting captioned "Sugar Harvest in Louisiana and Texas" by Franz Hölzlhuber painted about 1860. Excavation of a sugar evaporator has been reported from Jackson County (Freeman and Fawcett 1980; a good review of sugar cane processing is provided by Fox [1983]). A furnace similar to the Rainbow site was recorded during survey work at Lake $O$ ' The Pines (Linder-Linsley and Lindsay 1998) and one was described but not found at Cooper Lake (Green et al.1996).

The furnace at the Rainbow site compares favorably to recently constructed furnaces in Smith County and in Rusk County. Loy Gilbert of Tyler had a furnace constructed on his property in rural Smith County more than 20 years ago. He operated the furnace as an annual activity for several years, but has not done so for more than 10 years. We visited his furnace, and although made of concrete blocks, it is similar to the Rainbow site except that the Gilbert furnace was constructed above ground, the firebox does not have a clear separation between it and the flue, and the chimney is obvious. The firebox is lower than the floor of the flue, which rises up toward the middle of the flue and then drops slightly as the chimney is reached. The top of the furnace drops slightly from the firebox to the chimney so that the evaporating liquid will flow downhill to the end of the pan where the syrup is drained off. According to Gilbert (2001 personal communication), processing was done in October or November and was a very hot process. Although processing was done for several days, it was not a 24 hour activity. Rather, the fire was allowed to go out at night and the pan and other equipment were cleaned. Then the process began the next day until all the cane had been squeezed and the juice processed. A similar process is carried out every fall at the Depot Museum in Henderson (Depot Museum Volunteers 2000). The furnace at the museum was 
constructed following directions in a manual published by the U.S. Department of Agriculture in the 1940s.

Further information about syrup mills is provided by Stanly $(1979: 164,166)$. The author notes that the mill was located near the furnace and that the furnace area was invariably covered with a pole shed in order to provide shade during processing. Tools, including skimmers, juice pushers, and a stained rag used for blocking the flow of the juice in the evaporators, were often found hanging from the rafters of the shed. He further notes: "Sometimes a wooden barrel covered with a sack strainer would be placed near the furnace for collecting the skimmings. When full, a prescribed amount of shelled com was added. After two weeks or more of fermentation, a somewhat cloudy timid yellow brew called cane beer was offered to visitors who dared to partake. The syrup mill was a social institution for farm residents."

The Rainbow site is a good example of the fumace at a syrup mill site. No evidence was found of the mill itself, but it certainly would have been removed from the site when it was abandoned. In fact, the mill at the Depot Museum in Henderson is almost 100 years old as are the mills at the Gilbert syrup mill. Likewise, the pan from the Rainbow site would also have been traded, sold, or given to someone clse when the Rainbow site was abandoned. The pans at the two modern sites discussed above are also pieces with considerable antiquity.

\section{ACKNOWLEDGEMENTS}

The author thanks everyone involved in the preparation of this article. In particular, I want to thank Dr. David Riddle, PE of Adams Consulting Engineers, Inc. for his involvement throughout the project. I also want to thank Jeremy Rowden, Environmental Specialist, at Adams Consulting Engineers, Inc. for providing copies of aerial photographs extending back to 1939.

In addition, numerous people provided information about the archaeology and history of Gregg County and the Longview area. These folks included Dr. Norman Black, several individuals at the Gregg County Historical Museum, and Patty Haskins. Information about the sawmill industry was first secured at Morgan Power Saw in Longview who then suggested we contact Bobo Lumber. At Bobo Lumber, Mr. J. D. Winstead spent considerable time sharing his experiences with us and assisting in the evaluation of the insert saw teeth we recovered. Loy Gilbert of Tyler provided a wealth of information about sugar cane syrup mills. Susan Weaver, Director of the Depot Museum in Henderson, and Virginia Knapp of the Rusk County Historical Society, shared their experiences with syrup mills. Members of the Shelby County Historical Society provided pictures and descriptions of syrup mills in the Center, Texas area. I also want to thank our crew of historic artifact consultants who regularly meet with Mac Wimberly at Southwest Feed Mill in Dallas and lent their perspectives on artifact functions. Artifact illustrations were prepared by Lance K. Trask of AR Consultants. 


\section{REFERENCES CITED}

Abernethy, Francis E.

1997 Barns \& Outbuildings. In Built in Texas, edited by Francis E. Abernethy, Publications of the Texas Folklore Society XIII: 147, E-Heart Press, Waco.

Depot Museum Volunteers

2000 The Herilage Syrup Festival Cookbook, a Book of Syrup Recipes. Compiled by the Depot Museum Volunteers, Henderson, Texas.

Fox, Daniel E.

1983 Traces of Texas History, Archeological Evidence of the Past 450 Years. Corona Publishing Company, San Antonio.

Freeman, Martha D. and William B. Fawcett

1980 The Antebellum Period in the Stephen F. Aust in Colony: Historical and Archeological Research in the Palmetto Bend Reservoir Area, Jackson County, Texas. Part I: The Sutherland Plantation and the Alabama Settlement: A Study in Cluster Migration, Part II: Archeological Investigations at Historic Sites. Research Report No. 70, Palmetto Bend Reservoir Series, Vol. 5. Texas Archeological Survey, The University of Texas at Austin.

Fontana, Bernard L.

1965 The Tale of a Nail: On the Ethnological Interpretation of Historic Artifacts. Florida Anthropologist XVIII(No. 3):Pt 2:85-102.

Graves, Jim

1996 Brick Manufacturers of the United States. Privately published by the author.

Green, Melissa M., Duane E. Peter, and Donna K. Shepard

1996 Friendship: An African-American Community on the Prairie Margin of Northeast Texas. Miscellaneous Report of Investigations, Number 81. Geo-Marine, Inc., Plano.

Gurcke, Karl

1987 Bricks and Brickmaking, A Handbook for Historical Archaeology. University of Idaho Press, Moscow.

Linder-Linsley, Sue E. and Linda D. Lindsay

1998 Wright Patman Lake and Lake O'The Pines, Cass, Camp, Marion, and Morris Counties, Texas: Cultural Resources Survey 1996. Prepared for the U.S. Army Corps of Engineers, Fort Worth District by LL Consultants, Dallas and Atlanta, Texas. 
Longview Centennial Book Committec

1970 Longview, Texas Centennial, the long view of a hundred years, 1870-1970. Hudson Printing, Longview.

McWhorter, Eugene W.

1989 Traditions of the Land, The History of Gregg County, Texas. Gregg County Historical Foundation, longview.

Skinner, S. Alan and Floyd D. Kent

2000 Archaeological Reconnaissance in Eastern Wood County, Texas. Cultural Resources Report 2000-35. AR Consultants, Dallas.

Stanly, Thomas J.

1979 Barns and Outbuildings. In Built in Texas, edited by Francis E. Abernethy, Publications of the Texas Folklore Society, Number XLII: 148-173, E-Heart Press, Waco..

Tyler, Ron and Lawrence R. Murphy (editors) 1997 The Slave Narratives of Texas. State House Press, Austin. 